\title{
Creating Legacy Digital Stories: Do Males and Females Differ?
}

\author{
Neha Shivhare ${ }^{1}$, Luciane Maria Fadel ${ }^{2}$ and David Kaufman ${ }^{3 *}$ \\ ${ }^{1}$ Dayalbagh Educational Institute Deemed University, India \\ ${ }^{2}$ Federal University of Santa Catarina, Brazil \\ ${ }^{3}$ Simon Fraser University, Burnaby, Canada
}

Submission: September 9, 2019; Published: September 25, 2019

*Corresponding author: David Kaufman, Simon Fraser University, Burnaby, Canada

\begin{abstract}
This study investigated whether the types of 'legacy' digital stories created by older adults to share with their families, friends and others, differed between males and females. Older adults participating in ten-week Elder's Digital Storytelling courses in Western Canada created their legacies as short digital stories. One hundred stories were thematically analyzed and iteratively coded by three faculty members. The findings suggest there are some notable differences between older males and females in their legacy digital stories.
\end{abstract}

Keywords: : Digital storytelling; Older adults; Elders; Legacy; Story types

\section{Introduction}

This study investigated whether the types of 'legacy' digital stories created by older adults to share with their families, friends and others differed between males and females. These short digital stories were created by older adults during tenweek Elder's Digital Storytelling courses offered in Western Canada. For fulfilling the objective of the present study, 100 stories were thematically analyzed and iteratively coded by three researchers who are all faculty members at universities in their own countries. This research is unique in the area of types and features of the stories developed by the older adults. We could not find many studies trying to explore the types and features of the stories developed by to male and female older adults. lambert [1]. defines four kinds of personal stories, which focus on a specific element of narrative. He argues that a personal story can be about an important person, or a place, or about what someone does. A story about an important person concerns a Character or Memorial story. The former recognizes a relationship while the latter is about honoring and remembering people. Both narratives are based on a representation of characters in a series of chronological events [2]. When someone tells a story about an event [3], usually it is about an Adventure or Accomplishment. Accomplishment stories activate life scripts because people tend to tell transitional events like graduation, marriage, starting a new job, etc. [4]. Places are also an essential kind of stories because they define the space (Ryan, 2009) where the moments were lived. Other kinds of stories are about recovery, love or discovery. [5] defines legacy as a way of "leaving something behind after death and making meaning" of life's end (p. 313). He found "kindness of others, creativity, personal talents, stories of overcoming obstacles, stories of growth, and strong identification with certain roles" as the major themes of the life narratives of 38 women ranging in the age 31 to 90 years (p. 320). This study examined differences between males and females with respect to the types of stories they created.

\section{Research Question}

The research question addressed in this study was: Are there differences between older females and males regarding their types of legacy stories?

\section{Method}

The present research is based on the qualitative analysis of 100 stories created by older adults in the age group ranging from 55 to 95 years of age. These stories were the transcripts of digital stories created as a result of the participation of older adults in a ten-week digital storytelling course conducted as a part of a larger project aiming to use technology to enhance the lives of old adults (AGE-WELL http://agewell-nce.ca/).

\section{The Digital Storytelling Course}

The digital storytelling course is described in more detail elsewhere (Hausknecht, Vanchu-Orosco, \& Kaufman, 2018), so a shorter description is provided here. Participants were asked 
at the start to think of a story from their life that was important or meaningful to them. This story would serve as a legacy that they would provide to their family, friends, and others. Course enrolments ranged in size from 6 to 10 participants. The courses lasted ten weeks and participants met once a week for two-hour sessions, with extra tutorial sessions provided for those who requested this.

Following story creation, participants digitized their work by combining voice, images, music, and sounds to illustrate their narrative. As expected, the participants ranged from those who worked with computers in their careers to those who had never used a computer. In addition to the course sessions, tutorials were offered midway through the course to provide supplementary assistance to those that needed extra help learning the digital storytelling software. We Video, a browserbased digital storytelling software, was chosen as it is browserbased and thus allows for access on both Windows-based and Apple computers on the Internet. Thus, we expected that participants would spend some time working on their stories outside of the course.

Table 1: Framework used to code the digital stories.

\begin{tabular}{|c|c|}
\hline Digital Story Types & Sample Excerpts \\
\hline $\begin{array}{c}\text { Important person: Character, } \\
\text { Military }\end{array}$ & $\begin{array}{l}\text { "Grandma met the baby's father, Nathan, at a dance in East London. He was a smooth-talking American soldier. She } \\
\text { was soft-spoken, shy and very naïve. They got married and went to Gary, Indiana, and moved in with his mother, a } \\
\text { nasty woman who took an instant dislike to her new daughter-in-law." (Character) }\end{array}$ \\
\hline $\begin{array}{l}\text { About an event or place: } \\
\text { Place| Event, Adventure, } \\
\text { Accomplishment, Family Life, } \\
\text { Immigration, History, Travel }\end{array}$ & $\begin{array}{l}\text { "Lyons Falls was a paper-mill town, and as a little kid, I thought I knew as much as anyone about making paper. My } \\
\text { dad was the chief engineer at the mill, and I always went along when he toured family visitors around. I've traveled } \\
\text { down into the depths in a scary, open cage of an elevator, down into the ear-splitting noise of the giant metal rollers } \\
\text { that spit out huge rolls of paper, down to where the pulp from chipped wood was brewed in massive vats, and the } \\
\text { floor was so slippery with moisture, you could skate on it." (Place) } \\
\text { "Uncle Einar told me that housing was plentiful in Vancouver and he would help me to get settled. With my mother's } \\
\text { blessing, I left my country and landed in Vancouver." (Immigration) } \\
\text { "As history has chronicled, Jews were being ostracized and persecuted. It was no longer safe to be out on the streets } \\
\text { in case we were arrested. (Historical) }\end{array}$ \\
\hline $\begin{array}{l}\text { About what someone does: } \\
\text { Career| School life }\end{array}$ & $\begin{array}{l}\text { "I attended a one-room schoolhouse through 6th Grade and then attended a regional high school in the nearest town } \\
\text { from Grade } 7 \text { through Grade } 12 \text {....Therefore, upon graduating from high school, I was faced with a career decision; } \\
\text { my choices were: to become a nurse, a teacher, or attend a one-year business education course at my high school. I } \\
\text { chose the latter." (School life) }\end{array}$ \\
\hline $\begin{array}{l}\text { Other: Love, Discovery, } \\
\text { Wisdom, Tragedy, Passion, } \\
\text { Friendship, Exceptional, } \\
\text { Philosophical, Spiritual }\end{array}$ & $\begin{array}{l}\text { "With time passing, the bond between us got tighter. It was as if all this time we were building up a wall, brick-by- } \\
\text { brick, to protect us from what was to come, as if we made a mutual, silent promise to help and be there for each } \\
\text { other forever". (Love) } \\
\text { "I hurried back home, got on the computer and found out that it was the holding building for the Japanese going } \\
\text { back to Japan in 1946. This was later confirmed by someone who was working there at that time". (Discovery) } \\
\text { "Now, you might conclude, in life, human or animal kingdom, enemies can become friends in need. While the crows } \\
\text { raided Daisy Duck's first two nests, but when they saw the big, bad eagle flying towards them when they were walk- } \\
\text { ing from pond to pond, the crows cawed loudly warning Mother Duck and her ducklings of the danger. The crows } \\
\text { did their friendly deed when in need." (Wisdom) } \\
\text { "The next morning, we took her to the doctor, and he told us she had MS. That is multiple sclerosis". (Tragedy) }\end{array}$ \\
\hline
\end{tabular}

As many stories comprised more than one story type, stories were coded with a 'primary' code, i.e., the main focus of the story, and a 'secondary' code, i.e., the additional story type that was an important aspect of the story. Two faculty member researchers, supported by a third one, used this framework for several rounds of coding. The codes for each script were then

\section{Participants}

Participants in this study consisted of 100 older adults in the age group above 55 years, residing in Greater Vancouver, who participated in the various ten-week digital storytelling courses conducted by our team during the period from 2015-2018. Most of the participants provided scripts of their digital stories, and a trained person transcribed the remaining ones from the videos that were created. The scripts were then used to do the coding for the current study. A questionnaire was given to the participants during the first course session asking for demographic and background information.

\section{Developing a framework for coding the stories}

The researchers developed a coding framework by reviewing the related literature and a number of story transcripts. The Digital Storytelling Cookbook [1] provided the foundational types of stories to be analyzed. The authors then added several story types to build a robust framework that encompassed the specificities of the stories. (Table 1) Column 1: lists the digital story types coded in our analysis.

\section{Sample Excerpts}




\section{Open Access Journal of Gerontology \& Geriatric Medicine}

for each script then were added to the dataset containing each participant's demographic and background data. The statistical analysis was conducted using using SPSS24, and frequencies and crosstabs were run on the data.

\section{Discussion of Results}

(Table 2) shows the demographic details of the 100 older adult participants who participated in the digital storytelling course and shared their stories. The demographic details were available for 100 older adults, comprising 84 females and 16 males. Not all participants provided complete demographic data.
(Table 3) shows the comparisons for the story types between females and males. Many more older females $(n=84)$ than males $(\mathrm{n}=16)$ attended our courses. Among all the 23 types of the stories created by the older adults, character ranked first for females (41.7\%) and wisdom ranked first for males (37.5\%). The category that ranked second for both was place (created by $28.6 \%$ females and $31.3 \%$ males) followed by family life for females $(22.6 \%)$ and character for males $(31.1 \%)$ at the third rank.

Table 2: Demographics of older adults who created digital stories.

\begin{tabular}{|c|c|c|c|c|c|}
\hline \multirow{2}{*}{ Demographics } & \multirow{2}{*}{ Category } & \multicolumn{2}{|c|}{ Female $(\mathrm{N}=84)$} & \multicolumn{2}{|c|}{ Male $(n=16)$} \\
\hline & & Frequency (n) & Percent (\%) & Frequency (n) & Percent (\%) \\
\hline \multirow{4}{*}{ Age } & $55-64$ & 16 & 23.9 & 1 & 7.1 \\
\hline & $65-74$ & 22 & 32.8 & 7 & 50 \\
\hline & 75 and over & 29 & 43.3 & 6 & 42.9 \\
\hline & Total & 67 & 100 & 14 & 100 \\
\hline \multirow{3}{*}{ Marital } & Single & 44 & 63.8 & 3 & 21 \\
\hline & Partner & 25 & 36.2 & 11 & 79 \\
\hline & Total & 69 & 100 & 14 & 100 \\
\hline \multirow{3}{*}{ Living Situation } & Alone & 38 & 55.1 & 3 & 21.4 \\
\hline & With others & 31 & 44.9 & 11 & 78.6 \\
\hline & Total & 69 & 100 & 14 & 100 \\
\hline \multirow{3}{*}{ Home } & Own place & 47 & 75.8 & 11 & 84.6 \\
\hline & Assisted living/nursing & 15 & 24.2 & 2 & 15.4 \\
\hline & Total & 62 & 100 & 13 & 100 \\
\hline \multirow{4}{*}{ Education } & High School or less & 12 & 17.4 & 0 & 0 \\
\hline & College/2-yr. degree & 43 & 62.3 & 4 & 30.8 \\
\hline & Postgraduate & 14 & 20.3 & 9 & 69.2 \\
\hline & Total & 69 & 100 & 13 & 100 \\
\hline \multirow{4}{*}{ Retired } & Yes & 68 & 94.4 & 14 & 100 \\
\hline & No & 3 & 4.2 & 0 & 0 \\
\hline & Never worked & 1 & 1.4 & 0 & 0 \\
\hline & Total & 72 & 100 & 14 & 100 \\
\hline
\end{tabular}

Table 3: Comparison of female and male older adults' types of digital stories

\begin{tabular}{|c|c|c|c|c|c|c|}
\hline \multirow{2}{*}{ Types of Stories } & \multicolumn{3}{|c|}{ Female $(\mathrm{N}=84)$} & \multicolumn{3}{|c|}{ Male $(n=16)$} \\
\hline & Primary (\%) & Secondary (\%) & Total (\%) & Primary (\%) & Secondary (\%) & Total (\%) \\
\hline Character & 28.6 & 13.1 & 41.7 & 12.5 & 18.8 & 31.3 \\
\hline Place & 17.9 & 10.7 & 28.6 & 6.3 & 25 & 31.3 \\
\hline Family Life & 9.5 & 13.1 & 22.6 & 0 & 18.8 & 18.8 \\
\hline Accomplishment & 2.4 & 14.3 & 16.7 & 18.8 & 0 & 18.8 \\
\hline Career/School life & 13.1 & 3.6 & 16.7 & 12.5 & 0 & 12.5 \\
\hline Historical & 2.4 & 11.9 & 14.3 & 6.3 & 6.3 & 12.6 \\
\hline Love & 6 & 9.5 & 15.5 & 6.3 & 0 & 6.3 \\
\hline Immigration & 2.4 & 8.3 & 10.7 & 12.5 & 0 & 12.5 \\
\hline Wisdom & 0 & 3.6 & 3.6 & 12.5 & 25 & 37.5 \\
\hline
\end{tabular}




\begin{tabular}{|c|c|c|c|c|c|c|}
\hline Adventure & 4.8 & 6 & 10.8 & 12.5 & 0 & 12.5 \\
\hline Discovery & 2.4 & 6 & 3 & 0 & 6.3 & 6.3 \\
\hline Recovery & 6 & 1.2 & 7.2 & 0 & 0 & 0 \\
\hline Travel & 2.4 & 4.8 & 7.2 & 6.3 & 0 & 6.3 \\
\hline Military & 0 & 4.8 & 4.8 & 0 & 6.3 & 6.3 \\
\hline Passion & 2.4 & 4.8 & 7.2 & 0 & 6.3 & 6.3 \\
\hline Philosophical & 0 & 3.6 & 3.6 & 0 & 0 & 0 \\
\hline Spiritual & 0 & 0 & 0 & 6.3 & 0 & 6.3 \\
\hline Exceptional & 1.2 & 0 & 1.2 & 0 & 0 & 0 \\
\hline Friendship & 1.2 & 0 & 1.2 & 0 & 0 & 0 \\
\hline Tragedy & 0 & 1.2 & 1.2 & 0 & 0 & 0 \\
\hline Survivor & 0 & 0 & 0 & 0 & 0 & 0 \\
\hline Instructional & 0 & 0 & 0 & 0 & 0 & 0 \\
\hline Political & 0 & 0 & 0 & 0 & 0 & 0 \\
\hline
\end{tabular}

There were many similarities between males and females in the types of legacy digital stories created during the digital storytelling courses. However, a few notable differences emerged. More females created stories about a character (41.7\%) compared to males (31.3\%). The character stories were often about a deceased husband or parent. Females also created more stories about love (15.5\%) compared to males $(6.3 \%)$. Surprisingly, more males created 'wisdom' stories (37.5\%) compared to females (3.6\%). The wisdom stories generally were more reflective or contained a life lesson Our next step will be to examine the associations between the different types and features of stories and the demographic characteristics of storytellers. We wish to determine whether story types are different based on age, social living conditions, and other demographic factors.

\section{References}

1. Lambert J (2010) Digital Storytelling Cookbook Berkley CA: Digital Diner Press, USA.

2. Chatman S (1978) Story and discourse Narrative structure in fiction and film. Ithaca: Cornell University Press, New York.

3. Abbott HP (2008) The Cambridge Introduction to Narrative Cambridge: Cambridge University Press, UK.

4. Bohn A (2010) Generational differences in cultural life scripts and life story memories of younger and older adults. Applied Cognitive Psychology 24(9): 1324-1345.

5. Hunter EG (2008) Beyond Death: Inheriting the Past and Giving to the Future, Transmitting the Legacy of One's Self. Omega (Westport) 56(4): 313-329. 